\title{
Life cycle assessment of switchgrass-derived ethanol as transport fuel
}

\author{
Yu Bai $\cdot$ Lin Luo $\cdot$ Ester van der Voet
}

Received: 20 August 2009 /Accepted: 24 February 2010/Published online: 31 March 2010

(C) The Author(s) 2010. This article is published with open access at Springerlink.com

\begin{abstract}
Background, aim, and scope The increasing gasoline price, the depletion of fossil resources, and the negative environmental consequences of driving with petroleum fuels have driven the development of alternative transport fuels. Bioethanol, which is converted from cellulosic feedstocks, has attracted increasing attention as one such alternative. This study assesses the environmental impact of using ethanol from switchgrass as transport fuel and compares the results with the ones of gasoline to analyze the potential of developing switchgrass ethanol as an environmentally sustainable transport fuel.

Methods The standard framework of life cycle assessment from International Standards Organization was followed. To compare the environmental impact of driving with E10 and E85 with gasoline, "power to wheels for 1-km driving of a midsize car" was defined as the functional unit. The product system consists of all relevant processes, from agriculture of switchgrass, throughout the production of ethanol, blending ethanol with gasoline to produce E85 and E10, to the final vehicle operations. The transport of all products and chemicals is also included in the system boundaries. An allocation based on energy content was applied as a baseline, and market price-based allocation was applied for a sensitivity analysis.

Results and discussion With regard to global warming potential, driving with switchgrass ethanol fuels leads to less greenhouse gas (GHG) emissions than gasoline: $65 \%$
\end{abstract}

Responsible editor: Niels Jungbluth

Y. Bai $\cdot$ L. Luo $(\bowtie) \cdot$ E. van der Voet

Department of Industrial Ecology,

Institute of Environmental Sciences (CML),

Faculty of Science, Leiden University,

P.O. Box 9518, 2300 RA Leiden, The Netherlands

e-mail: luo@cml.leidenuniv.nl reduction may be achieved in the case of E85. Except for global warming and resource depletion, driving with ethanol fuels from switchgrass does not offer environmental benefits in the other impact categories compared to gasoline. Switchgrass agriculture is the main contributor to eutrophication, acidification, and toxicity. Emissions from bioethanol production cause a greater impact in photochemical smog formation for ethanol-fueled driving. Conclusions and recommendations Switchgrass ethanol indeed leads to less GHG emissions than gasoline on a life cycle basis; however, the problem has been shifted to other impacts. Improvement of switchgrass yields and development of ethanol production technologies may be the key to lower environmental impact in the future. For a more comprehensive evaluation of using bioethanol as transport fuel, more impact categories need to be included in the life cycle impact assessment. A comparison with bioethanol from other feedstocks, based on similar methodological choices and background data, would provide more insight in the environmental benefits of switchgrass as a feedstock.

Keywords Bioethanol - Environmental impact - Gasoline · E10 $\cdot$ E85 $\cdot$ Switchgrass

\section{Introduction}

An increasing demand for energy has led to an increase in the price of crude oil and an increased risk for depletion of fossil resources (Energy Information Administration 2009). The development of biofuels as transport fuel has the potential to reduce both greenhouse gas (GHG) emissions and the reliance on fossil fuels. Bioethanol is the most common biofuel, which has a large potential to substitute gasoline as a transport fuel. So far, many studies on the life cycle assessment of bioethanol as transport fuel focus on first-generation 
bioethanol, which is converted from conventional crops, such as corn, wheat, sugar cane, and sugar beet (Halleux et al. 2008; Luo et al. 2009b; Patyk and Reinhardt 2002; Shapouri and McAloon 2002). It has been signaled that producing energy from such crops is very land and water intensive (Nguyen and Gheewala 2008; Renouf et al. 2008; Silalertruksa and Gheewala 2009). Global demand for food is expected to keep increasing in the future (Rosegrant et al. 2001), and demand for transportation fuels is expected to increase even more rapidly (Energy Information Administration 2009), which implies a potential competition between land for food and land for energy.

To avoid conflict in demand between food and energy, cellulosic technology has been developed recently to convert ethanol from lignocelluloses rather than sugar or starch (Faaij 2006). The application of second-generation bioethanol has the potential to reduce fossil fuel use and achieve better environmental performance, while at the same time avoiding competition with food supply, as cellulosic feedstocks are mainly from agriculture residues and lignocellulosic plants which do not need the same soil fertility as for conventional crops. Some life cycle assessment (LCA) studies of second-generation bioethanol as transport fuels have been conducted, and the feedstocks are mainly bagasse, corn stover, and switchgrass (Kadam 2002; Luo et al. 2009a; Sheehan et al. 2004; Spatari et al. 2005; Wu et al. 2006). Switchgrass (Panicum virgatum), a warm season grass, is not a food supply; thus, it is one of the popular lignocellulosic feedstocks for second-generation ethanol production. Although it is not a residue but a crop, it can be grown on marginal lands which cannot be used for food production. Since switchgrass does not need high soil nutrient concentrations, it does not have the annual preparation requirements and requires less chemical inputs than food crops (Mitchell et al. 2008; Sokhansanj et al. 2009).

Previous LCA studies of switchgrass ethanol focus on greenhouse gas emissions. The research by Spatari et al. (2005) shows that, compared to gasoline, GHG emissions reduction can reach 57\% when using E85 for vehicle driving, and greater reduction can be achieved in the future for the improvement of the yield of switchgrass and ethanol production. Wu et al. (2006) use the Greenhouse gases, Regulated Emissions, and Energy use in Transportation model to analyze the life cycle GHG emissions of transport fuel from switchgrass, and the results indicate that, for E85, the GHG reductions were $60-62 \%$ compared to gasoline. Without regard to final vehicle operations by ethanol fuels, LCA studies even show a reduction of GHG emissions of $94 \%$ per megajoule on average, compared to gasoline (Schmer et al. 2008).

However, the environmental impacts of switchgrass ethanol as transport fuel do not only include global warming. Other impact categories should also be taken into account to evaluate the switchgrass ethanol as transport fuels compre- hensively. This study carries out a life cycle assessment on switchgrass ethanol to evaluate the environmental performance of using ethanol as transport fuel compared with gasoline with a more complete set of impacts.

\section{Methodology}

\subsection{Functional unit and alternatives}

The functional unit in this study is defined as "power to wheels for $1-\mathrm{km}$ driving of a midsize car". Neither the production nor the disposal of the car is taken into account but only its energy requirements in driving, similar to the assumptions by Luo et al. (2009b). For the usage of ethanol as transport fuel, two applications were reported (Fu et al. 2003). The first one is that, for a standard gasoline engine, typically $5 \%$ to $20 \%$ ethanol mixed in gasoline can be used directly. The other is blending high percentage ( $85 \%$ to $100 \%$ ) ethanol into gasoline. For the latter application, specific flexible fueled vehicles with internal combustion engine designed to run on more than one fuel are required. With the progress of vehicle design and transport fuel using bioethanol in the future, E10 as well as E85 are taken into account in this study. Pure ethanol is also considered, but only as a reference, and conventional transport fuel gasoline is included for comparative purpose. Therefore, the alternative systems in this study consist of E100, E85, E10, and gasoline.

\subsection{System boundaries}

Figure 1 shows the product system including all relevant processes, from agriculture of switchgrass, throughout the production of pure ethanol, E85, and E10, to final vehicle operations, and all transport sections.

The switchgrass agriculture process was built on the base case scenario of switchgrass from the report by Bullard and Metcalfe (2001). However, to provide a more realistic approach in the management of switchgrass agriculture, one modification was made: in the base case, the fertilizer input is applied only in the preparation year, but from the literature, it appears that application also in the other harvesting years is more realistic. Annually, $100 \mathrm{~kg}$ per hectare of nitrogen fertilizers are assumed to be applied. The inputs, outputs, and emissions associated to the agricultural activities are summarized in Tables 1 and 2, respectively.

The technical data of the ethanol production plant can be found in the report by Guerra Miguez et al. (2009). The conversion of switchgrass to ethanol consists of four steps: feedstock pretreatment, enzyme hydrolysis, fermentation, and production recovery. An ammonia fiber explosion operation was chosen and optimized to recover $99 \%$ ammonia that is used for pretreatment, and simultaneous saccharification and 


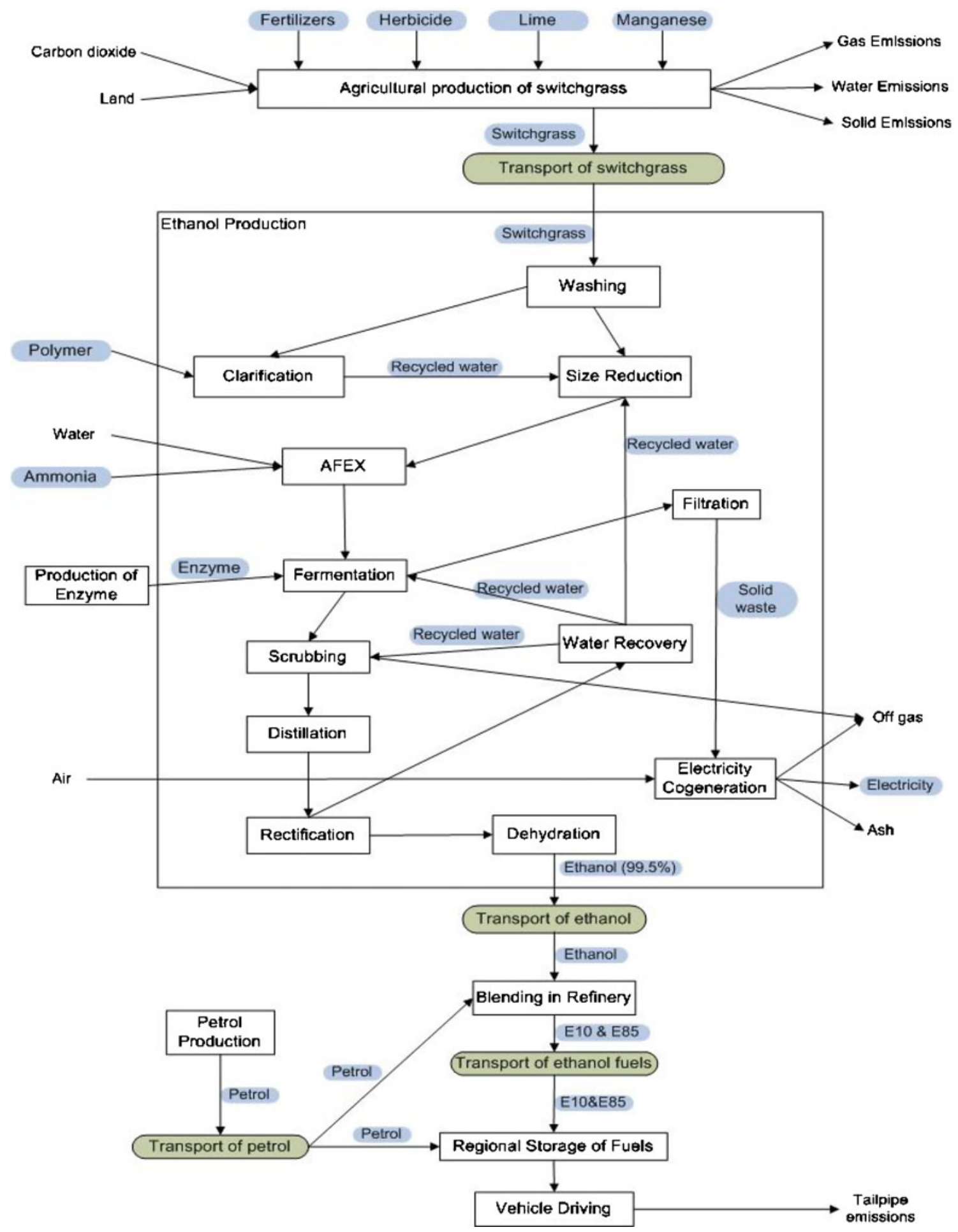

Fig. 1 The life cycle of ethanol from switchgrass

cofermentation operation is used to produce ethanol. The technical data used for the production of the cellulase enzyme are obtained from Wooley et al. (1999). The different wastes produced during the process are used in a cogeneration unit in order to supply all the steam and electricity required in the plant. The surplus electricity is the coproduct from the final step and can be sold to the local grid (Guerra Miguez et al. 2009). The end-use stage of ethanol fuel life cycle is fuel combustion via vehicle operation. In this unit process, a midsize car was chosen, and only tailpipe emissions are taken into account to serve the purpose of this studyethanol as transport fuel. 
Table 1 Agricultural inputs and outputs over 20 years

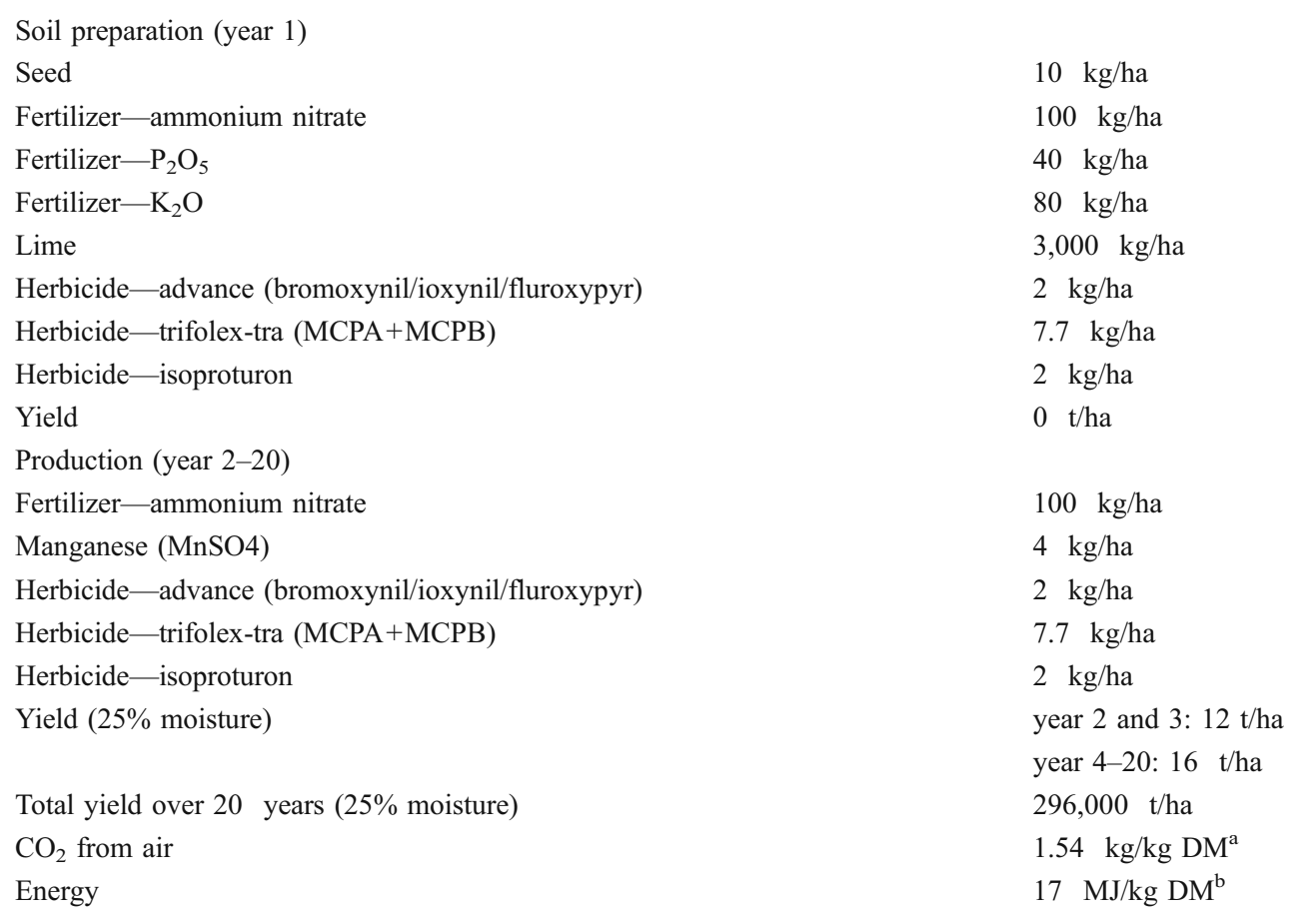

${ }^{\text {a }} \mathrm{C}$ content is $42 \% \mathrm{w} / \mathrm{w}$

${ }^{b}$ The energy content corresponds to the upper heating value of the dry biomass assumed to be $20 \mathrm{~km}$. The transport distance of the regional storage from the refinery is following the data from ecoinvent database (http://www.ecoinvent.org/), which is $33.7 \mathrm{~km}$.

Table 2 Environmental emissions in switchgrass agriculture over 20 years

\begin{tabular}{|c|c|c|c|}
\hline & Soil preparation (year 1) & Production (year 2-20) & Total 20 years \\
\hline \multicolumn{4}{|l|}{ Emissions to air (kg/ha) } \\
\hline Nitrogen oxides & 1.02 & 1.02 & 20.5 \\
\hline Dinitrogen monoxide & 4.88 & 4.88 & 97.5 \\
\hline Ammonia & 2.43 & 2.43 & 48.6 \\
\hline \multicolumn{4}{|l|}{ Emissions to water $(\mathrm{kg} / \mathrm{ha})$} \\
\hline Nitrate & 48.00 & 48.00 & 960.00 \\
\hline Phosphorus to ground water & 0.06 & 0.06 & 1.20 \\
\hline Phosphorus to surface water & 0.28 & 0.25 & 5.03 \\
\hline Phosphorus from erosion to surface water & 0.71 & 0.71 & 14.20 \\
\hline Cadmium (Cd) & $3.90 \times 10^{-5}$ & $1.72 \times 10^{-6}$ & $7.17 \times 10^{-5}$ \\
\hline Copper $(\mathrm{Cu})$ & $3.21 \times 10^{-3}$ & $1.85 \times 10^{-3}$ & $3.84 \times 10^{-2}$ \\
\hline Zinc $(\mathrm{Zn})$ & $1.52 \times 10^{-2}$ & $5.53 \times 10^{-3}$ & 0.12 \\
\hline Lead $(\mathrm{Pb})$ & $2.60 \times 10^{-4}$ & $2.14 \times 10^{-5}$ & $6.67 \times 10^{-4}$ \\
\hline Chromium (Cr) & $2.11 \times 10^{-2}$ & $6.04 \times 10^{-3}$ & 0.14 \\
\hline \multicolumn{4}{|l|}{ Emissions to soil $(\mathrm{kg} / \mathrm{ha})$} \\
\hline Cadmium (Cd) & $1.79 \times 10^{-5}$ & $7.93 \times 10^{-7}$ & $3.29 \times 10^{-5}$ \\
\hline Copper $(\mathrm{Cu})$ & $1.21 \times 10^{-3}$ & $7.01 \times 10^{-4}$ & $1.45 \times 10^{-2}$ \\
\hline Zinc $(\mathrm{Zn})$ & $2.22 \times 10^{-3}$ & $8.05 \times 10^{-4}$ & $1.75 \times 10^{-2}$ \\
\hline Lead $(\mathrm{Pb})$ & $7.83 \times 10^{-4}$ & $6.52 \times 10^{-5}$ & $2.02 \times 10^{-3}$ \\
\hline Nickel (Ni) & $1.48 \times 10^{-3}$ & $7.69 \times 10^{-4}$ & $1.61 \times 10^{-2}$ \\
\hline Chromium (Cd) & $1.78 \times 10^{-3}$ & $5.09 \times 10^{-4}$ & $1.14 \times 10^{-2}$ \\
\hline
\end{tabular}




\subsection{Life cycle inventory: data sources and software}

The data for the switchgrass agriculture are mainly from the report by Bullard and Metcalfe (2001). Switchgrass is assumed to be planted on the prepared land for 20 years; after which, the land needs to be prepared again. The emissions during cultivation were calculated by using the input data from the base case scenario, via the methods described in the ecoinvent report (Nemecek and Kägi 2007). The data for the ethanol production process were taken from the study of Guerra Miguez et al. (2009), including the material and energy inputs and outputs, as well as the use of equipments. The tailpipe emissions in practice are very complex, due to the different vehicle types, road situations, and driving behaviors, etc. The data for tailpipe emissions of vehicle driving used in this study are based on a standard test procedure, covering a mix of driving on urban roads and on motorways, and some assumptions and calculations (Kelly et al. 1996; Luo et al. 2009a; Reading et al. 2002).

The background data were from the ecoinvent database version 1.3. The software tool Chain Management Life Cycle Assessment developed by Heijungs (2009) was used for inventory analysis and impact assessment.

\subsection{Life cycle inventory: allocation}

When bioethanol is produced, electricity is generated as a coproduct. For multifunctional systems in LCA, allocating the material and energy inputs and environmental emissions between the main product and coproducts/by-products is a vital issue. There is a stepwise allocation procedure in ISO 14044 (2006). Since the system has multiple outputs, we have to find a way to account for the coproduct as well. This can be done by systems expansion as applied by Luo et al. (2009a). It can also be done by physical or economic allocation. In line with EU Directive (Directive 2009; 2009/28/EC 2009), we use coproduct allocation based on the energy content of the two products - ethanol and electricity. As allocation based on mass is not applicable in this case, a sensitivity analysis using economic allocation was conducted.

In this study, allocation based on energy value of ethanol and electricity was applied, in line with EU Directive 2009 (2009/28/EC 2009). However, in order to understand the influence of different allocation methods in LCA study, economic allocation based on market prices was also applied and compared with energy-based partition.

\subsection{Life cycle impact assessment}

The following environmental impact categories have been assessed:

- Abiotic depletion potential (ADP)

- Global warming potential (GWP)

- Ozone depletion potential (ODP)

- Photochemical oxidation potential (POCP)

- Acidification potential (AP)

- Eutrophication potential (EP)

- Human toxicity potential (HTP)

- Ecotoxicity potential (ETP)

\subsection{Interpretation}

The choices and assumptions made during the analysis in this study were evaluated. A contribution analysis is performed to understand the contributions of specific pollutants and production processes to the total impact scores, and to find the reasons of the changes of environmental impacts from gasoline fueled to ethanol-fueled vehicle driving. Furthermore, various sensitivity analyses, determining the influence of the variations in assumptions,
Fig. 2 Contributions of the main processes to global warming potential using all four fuels

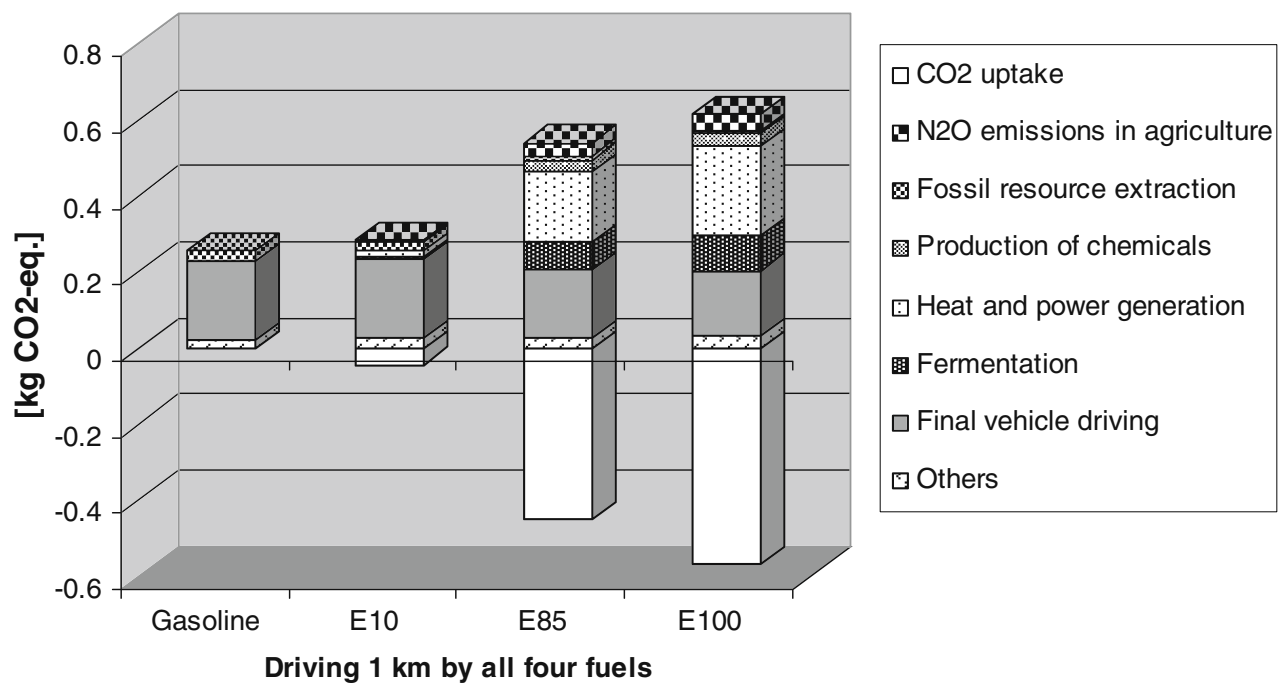



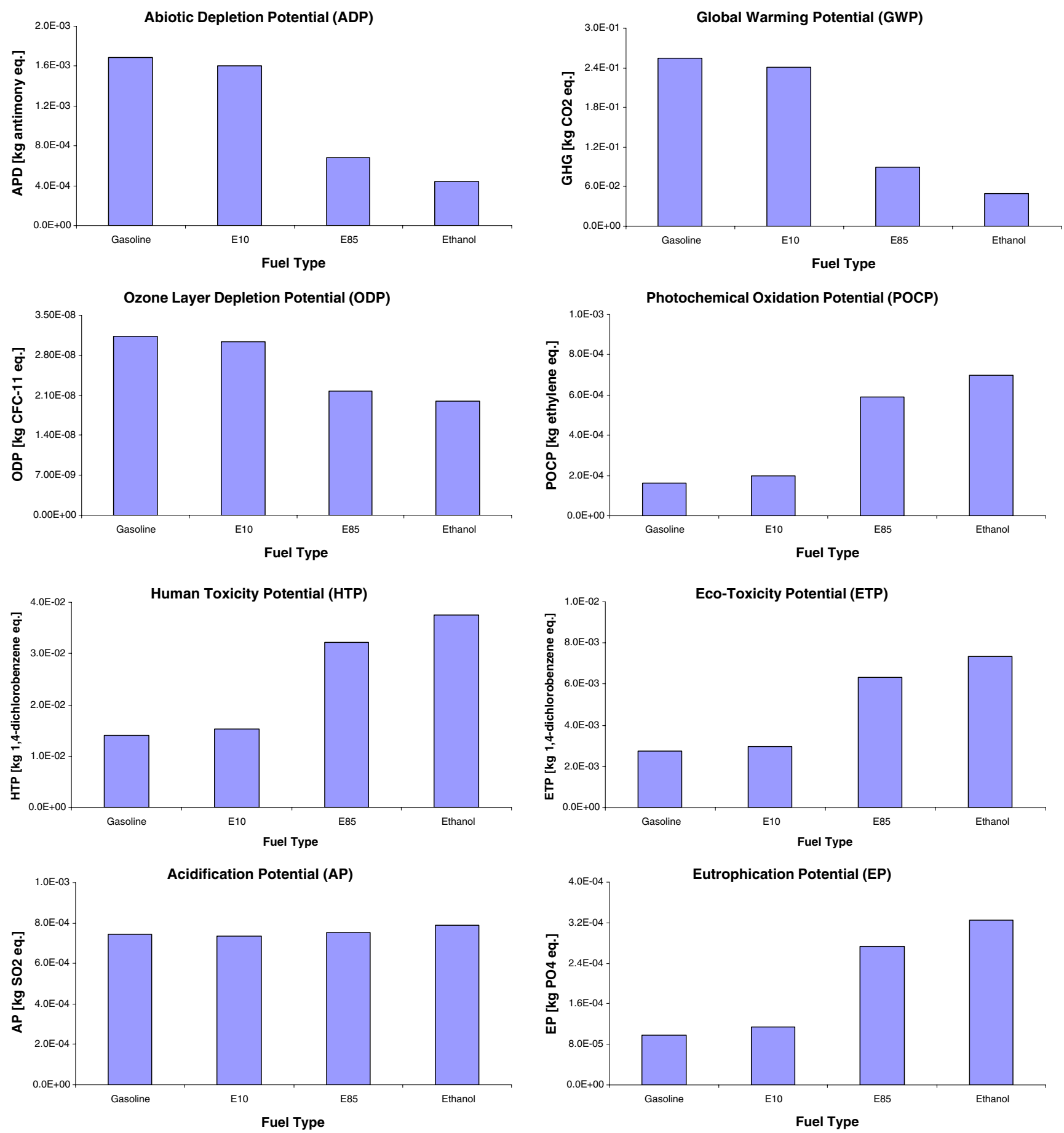

Fig. 3 Overall comparison results of the environmental impact of gasoline, E10, E85, and E100

Table 3 Comparison results of E10 and E85 in GWP with different allocation methods

\begin{tabular}{|c|c|c|c|c|}
\hline & \multicolumn{2}{|c|}{ Partitioning factor } & \multicolumn{2}{|c|}{ GWP of 1-km driving ( $\mathrm{kg} \mathrm{CO} \mathrm{CO}_{2}$ eq.) } \\
\hline & Ethanol & Electricity & E10 & E85 \\
\hline Energy allocation & 0.855 & 0.145 & 0.241 & 0.090 \\
\hline Economic allocation & 0.742 & 0.258 & 0.240 & 0.075 \\
\hline
\end{tabular}




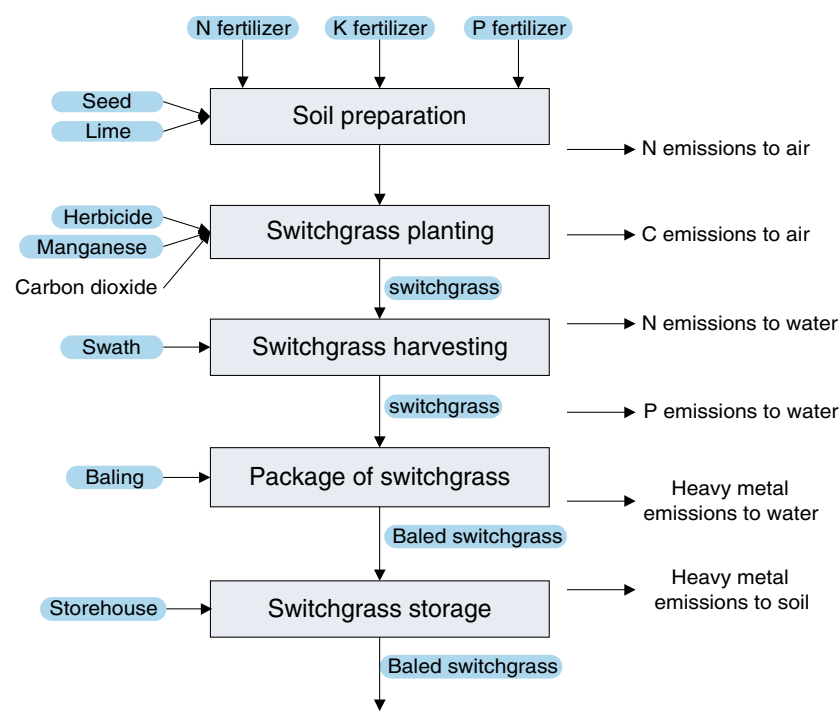

a Base scenario : including soil preparation

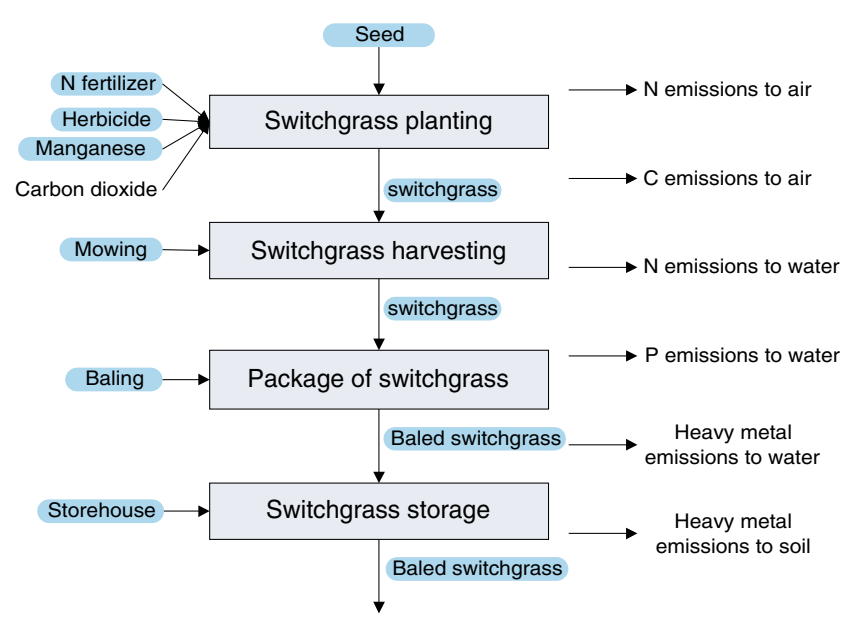

b Alternative scenario : excluding soil preparation

Fig. 4 The differences between two scenarios. a Including soil preparation. b Excluding soil preparation

method choices, and process data on the results, have been applied (Guinée et al. 2002; ISO 14040 2006).

\section{Results and discussion}

\subsection{LCA results}

The comparative results from the LCA of ethanol fuel and gasoline are shown in Figs. 2 and 3.

GHG mitigation is one of the most important issues globally. As can be seen in Fig. 2, switchgrass-derived ethanol as transport fuel produces less GHG emissions than conventional gasoline, and driving with E85 reduces substantially more GHG emissions than with E10. The primary (and obvious) reason of this significant decrease is the large amount of $\mathrm{CO}_{2}$ uptake in switchgrass agriculture. When driving with E10, about 5\% reduction of GWP is achieved compared to gasoline. A significant reduction of GHG emissions (65\%) is achieved when driving with E85. In this result, the difference in fuel efficiency is even included: for driving $1 \mathrm{~km}$ with $\mathrm{E} 85,0.099 \mathrm{~kg}$ of fuel is required, which is much larger than the $0.0665 \mathrm{~kg}$ of gasoline. With regard to abiotic resource depletion, replacing gasoline by fuel ethanol reduces the use of crude oil, which is the primary source for gasoline production. Emissions from crude oil production are avoided, causing a significant decrease in impacts in terms of ODP for ethanol-fueled driving.

Figure 3 indicates that, except for GWP, ADP, and ODP, driving with ethanol fuel from switchgrass does not offer advantages over gasoline regarding other environmental impacts. On the contrary, emissions in these impact categories are substantially higher. The higher level of photochemical oxidation caused by using ethanol fuels is mainly due to the acetaldehyde emission during bioethanol fermentation, which contributes $77 \%$ to POCP of vehicle driving with E85. The higher eutrophication score comes from switchgrass agriculture, especially the nitrate leaching to ground water and $\mathrm{NO}_{\mathrm{x}}$ to air from $\mathrm{N}$ fertilizer application. Agriculture is also the main contributor to human and ecotoxicity, due to the use of agrochemicals.
Table 4 Comparison results of environmental impacts for $1-\mathrm{km}$ driving by E100 in two scenarios

\begin{tabular}{llllc}
\hline Impact category & Unit & Base scenario & Alternative scenario & Range (\%) \\
\hline ADP & kg antimony eq. & $6.79 \times 10^{-4}$ & $6.52 \times 10^{-4}$ & -3.98 \\
GWP & kg CO 2 eq. & $8.96 \times 10^{-2}$ & $8.14 \times 10^{-2}$ & -9.15 \\
OPD & kg CFC-11 eq. & $2.18 \times 10^{-8}$ & $2.15 \times 10^{-8}$ & -1.37 \\
POCP & kg ethylene eq. & $5.91 \times 10^{-4}$ & $5.86 \times 10^{-4}$ & -0.85 \\
AP & $\mathrm{kg} \mathrm{SO}_{2}$ eq. & $7.52 \times 10^{-4}$ & $7.03 \times 10^{-4}$ & -6.52 \\
EP & $\mathrm{kg} \mathrm{PO}_{4}$ eq. & $2.69 \times 10^{-4}$ & $2.51 \times 10^{-4}$ & -6.69 \\
HTP & $\mathrm{kg} 1,4-\mathrm{DCB}$ eq. & $3.22 \times 10^{-2}$ & $2.89 \times 10^{-2}$ & -10.3 \\
ETP & $\mathrm{kg} 1,4-\mathrm{DCB}$ eq. & $6.33 \times 10^{-3}$ & $5.75 \times 10^{-3}$ & -9.12 \\
\hline
\end{tabular}


The result for acidification deserves special attention. Driving $1 \mathrm{~km}$ with E10 leads to the lowest impact in all alternative-fueled driving, lower than both gasoline and E85/E100. This can be explained as follows: AP is largely contributed by the upstream emissions of ammonia from agriculture and sulfur dioxide $\left(\mathrm{SO}_{2}\right)$ from oil refinery, and the downstream emissions of nitrogen oxides $\left(\mathrm{NO}_{\mathrm{x}}\right)$ from vehicle driving. The impact of ammonia from agriculture is more significant than $\mathrm{SO}_{2}$ from oil refinery. Thus, when shifting from gasoline to ethanol fuel for vehicle driving, the resulting AP level should increase. However, since in E10 only a small amount of ethanol is blended into gasoline, the difference in their upstream emissions is insignificant. The downstream $\mathrm{NO}_{\mathrm{x}}$ emissions are rather higher for gasoline on a per liter basis, but for the ethanol blends also show an increase proportional to the amount of fuel used to drive. The amount needed to drive $1 \mathrm{~km}$ is significantly higher in E85 and E100 than it is in E10. All these different mechanisms result in the lowest score (optimum fuel composition) for E10.

\subsection{Sensitivity analysis}

\subsubsection{Allocation method}

The multifunctionality in this study occurs in the ethanol production process, in which electricity is coproduced. The partitioning ratio between ethanol and electricity is calculated to be $0.855 / 0.145$ when applying allocation based on the energy content of the products. As stated in ISO 1404044 series (2006), whenever more than one allocation method can be applied, a sensitivity analysis is required. In this case, economic allocation can also be applied; a sensitivity analysis was conducted for comparative purposes. The average price of ethanol and electricity are taken as $0.357 € / \mathrm{kg}$ and $0.01 € / \mathrm{kWh}$, respectively (Lynd et al. 2005); thus, the allocation ratio between ethanol and electricity is $0.742 / 0.258$. The resulting GWP for driving $1 \mathrm{~km}$ with E10 and E85 is given in Table 3.

The results indicate that the choice of allocation methods has influence on the outcomes. GWP is used here to give an example of this effect. As allocation occurs in the ethanol production process, the influence of allocation method on GWP on driving with E85 is larger than E10. When driving $1 \mathrm{~km}$ with $\mathrm{E} 85,17 \%$ reduction of $\mathrm{GHG}$ emission is achieved by switching from energy content to economic values-based allocation. The analogous results are also observed in other impact categories.

\subsubsection{Soil preparation}

As switchgrass is a newly developed feedstock for bioethanol production, for the base scenario in this study, a key step in switchgrass agriculture is the soil preparation before planting and harvesting for large-scale production. In this case scenario, the first year is used only for land preparation; the switchgrass yield for the second and third year is assumed to be 12 and $16 \mathrm{t} / \mathrm{ha}$ in the consequent years. For large-scale production of conventional crops such as corn and sugar cane, such land preparations are usually not taken into account. In order to observe the effect of soil preparation on the outcomes, an alternative scenario in which soil preparation is excluded was assumed for sensitivity analysis. In this alternative scenario, $100 \mathrm{~kg} / \mathrm{ha}$ $\mathrm{N}$ fertilizer is applied as one important input every year, and herbicides for weeding and manganese for soil buffer are applied annually. The switchgrass yield is assumed to be 16 t/ha (with $25 \%$ moisture) per year. The soil preparation year without harvesting of switchgrass is outside the system boundary. The two scenarios including and excluding soil preparation are shown graphically in Fig. 4, and the comparative results are given in Table 4.

The results indicate that excluding soil preparation leads to better results from the perspective of GHG emissions reduction. The first reason is that some farming activities are only performed for soil preparation, like hoeing and plowing. These farming activities, which cause $\mathrm{CO}_{2}$ and $\mathrm{N}_{2} \mathrm{O}$ emissions, are excluded in the alternative scenario. The second one is that the average switchgrass yield is higher in the alternative scenario than the one in the base case-meaningless GHG are emitted per kilogram of switchgrass. The resulting GHG emission of 1-km driving
Table 5 Comparison results of environmental impacts and increases of E85 with different transport distances

\begin{tabular}{lllllll}
\hline Impact category & Unit & $20 \mathrm{~km}$ & $40 \mathrm{~km}$ & \multicolumn{3}{l}{$80 \mathrm{~km}$} \\
\hline ADP & kg antimony eq. & $6.79 \times 10^{-4}$ & $6.97 \times 10^{-4}$ & $+2.65 \%$ & $7.31 \times 10^{-4}$ & $+7.66 \%$ \\
GWP & kg CO 2 eq. & $8.96 \times 10^{-2}$ & $9.16 \times 10^{-2}$ & $+2.23 \%$ & $9.57 \times 10^{-2}$ & $+6.81 \%$ \\
OPD & kg CFC-11 eq. & $2.18 \times 10^{-8}$ & $2.22 \times 10^{-8}$ & $+1.83 \%$ & $2.28 \times 10^{-8}$ & $+4.59 \%$ \\
POCP & kg ethylene eq. & $5.91 \times 10^{-4}$ & $5.96 \times 10^{-4}$ & $+0.93 \%$ & $6.03 \times 10^{-4}$ & $+2.03 \%$ \\
AP & kg SO 2 eq. & $7.52 \times 10^{-4}$ & $7.61 \times 10^{-4}$ & $+1.23 \%$ & $7.86 \times 10^{-4}$ & $+4.52 \%$ \\
EP & kg PO 4 eq. & $2.69 \times 10^{-4}$ & $2.72 \times 10^{-4}$ & $+0.94 \%$ & $2.75 \times 10^{-4}$ & $+2.23 \%$ \\
HTP & kg 1,4-DCB eq. & $3.22 \times 10^{-2}$ & $3.24 \times 10^{-2}$ & $+0.68 \%$ & $3.29 \times 10^{-2}$ & $+2.17 \%$ \\
ETP & kg 1,4-DCB eq. & $6.33 \times 10^{-3}$ & $6.42 \times 10^{-3}$ & $+1.46 \%$ & $6.58 \times 10^{-3}$ & $+3.93 \%$ \\
\hline
\end{tabular}


with E100 is $9 \%$ lower than the one in the base case. However, the change of driving with E10 is rather small, since only $10 \%(v / v)$ bioethanol is mixed with gasoline. Similar reductions can be observed in the other impact categories. Besides GWP, other two large reductions appear in HTP and ETP, because of the reduction of heavy metal emissions from fertilizers and lime application in the switchgrass agriculture. The main reason for the reduction in acidification potential is that $\mathrm{NO}_{\mathrm{x}}$ emissions from agriculture in alternative scenario are much less than in base scenario. The primary emission in eutrophication is the phosphate and phosphorus emissions, and in the alternative scenario, no $\mathrm{P}$ fertilizers are applied in production years. The changes of ODP and POCP are very small as the main contributor to these two impacts is the ethanol production process.

\subsubsection{Transport distance}

The transport distances assumed are important for the outcomes, as lorries fueled with diesel are the major transport vehicles, which lead to significant environmental impact. Since the system under study has not been established in practice, the transport distances both from the switchgrass farm to the ethanol production plant and from the ethanol to the oil refinery are assumed to be $20 \mathrm{~km}$. The sensitivity of transport distance was analyzed to see the influence of the transport section in this study. To compare with, 20-, 40-, and 80-km transport distances were assumed. The comparative results are shown in Table 5.

It can be seen that the increase of transport distance leads to worse environmental performance in all impact categories, especially with regard to the level of ADP, GWP, and AP. Increasing transport distances leads to higher demand of diesel used in lorries, which contributes largely to ADP. One key consequence of the increasing use of diesel is $\mathrm{CO}_{2}$ emissions, resulting in the increase of GWP. All these changes are obtained for E85-fueled driving. For E10fueled driving, changes occurred in all impact categories are only up to $1 \%$.

\section{Conclusions and recommendations}

In this study, the LCA methodology was used to evaluate ethanol from switchgrass as a transport fuel on its environmental performance. The assessment results indicate that driving with switchgrass ethanol fuel as a replacement of gasoline contributes to the reduction of GHG emissions significantly, mainly due to the $\mathrm{CO}_{2}$ uptake from atmosphere in switchgrass agriculture. Driving $1 \mathrm{~km}$ using E85 reduces GHG emissions by $65 \%$ compared with driving with gasoline. The reduction of dependency on fossil fuels in ethanol-fueled driving leads to a better performance on abiotic depletion and acidification. However, switchgrass ethanol fuel performs worse regarding other impacts, including photochemical oxidation, eutrophication, and human and ecotoxicity. For acidification, driving with E10 gives the lowest impact. Sensitivity analyses show that the application of different allocation methods affects the LCA outcomes; the exclusion of soil preparation lowers the environmental impact of ethanol fuels, and increasing transport distance leads to worse performance.

The results from this LCA study on switchgrass ethanol as transport fuel are comparable with other LCA studies on second-generation bioethanol. There are potentially significant benefits offered by using ethanol derived from lignocellulosic feedstocks, especially in terms of GHG emissions (Fu et al. 2003; Kadam 2002; Luo et al. 2009a; Sheehan et al. 2004; Spatari et al. 2005; Wu et al. 2006). However, these benefits are offset by worse impacts in other categories, such as eutrophication, photochemical oxidation, and toxicity aspects. Careful management of switchgrass agriculture and improvements in ethanol production may be pathways to reduce these environmental impacts.

The overall life cycle environmental performance of using bioethanol as transport fuel requires further research, in which a number of critical impacts in biofuel LCA studies shall be considered that are presently out of scope, such as water and land use. Land use change (direct: LUC, indirect: ILUC) can be accompanied by sometimes large changes in GHG emissions from soils, as Fargione et al. argue (2008). Searchinger et al. (2008) show that including GHG emissions from LUC and ILUC may change a net GHG benefit into a net cost. We have not attempted to include these emissions in this study. To do this, methodology development in LCA is of crucial importance.

Acknowledgments This project is financially supported by the Netherlands Ministry of Economic Affairs and the B-Basic partner organizations (www.b-basic.nl) through B-Basic, a public-private NWO-Advanced Chemical Technologies for Sustainability (ACTS) program.

Open Access This article is distributed under the terms of the Creative Commons Attribution Noncommercial License which permits any noncommercial use, distribution, and reproduction in any medium, provided the original author(s) and source are credited.

\section{References}

Bullard M, Metcalfe P (2001) Estimating the energy requirement and $\mathrm{CO}_{2}$ emissions from production of the perennial grasses miscanthus, switchgrass and reed canary grass. ETSU B/U1/00645/REP

Energy Information Administration (2009) International Energy Outlook. U.S. Department of Energy, Washington, DC. Available online: http://www.eia.doe.gov/oiaf/ieo/index.html 
European Commission (2009) Directive 2009/28/EC of the European Parliament and of the Council of 23 April 2009 on the promotion of the use of energy from renewable sources and amending and subsequently repealing Directives 2001/77/EC and 2003/30/EC

Faaij APC (2006) Bio-energy in Europe: changing technology choices. Energy Policy 34:322-342

Fargione J, Hill J, Tilman D, Polasky S, Hawthorne P (2008) Land clearing and the biofuel carbon debt. Science 319:1235-1238

Fu GZ, Chan AW, Minns DE (2003) Life cycle assessment of bioethanol derived from cellulose. Int J Life Cycle Assess 8:137141

Guerra Miguez O, Siva siddarthan D, Suárez Zuluaga DA (2009) Technical and economical feasibility of production and ethanol from switchgrass. In: B-Basic Internal Report, Delft University of Technology, The Netherlands

Guinée JB et al (2002) Handbook on life cycle assessment operational guide to the ISO standards. Kluwer Academic Publishers, Dordrecht

Halleux H, Lassaux S, Renzoni R, Germain A (2008) Comparative life cycle assessment of two biofuels ethanol from sugar beet and rapeseed methyl ester. Int J Life Cycle Assess 13(3):184 189

Heijungs R (2009) Chain Management by Life Cycle Assessment software package (Version 5. 1). Department of Industrial Ecology. Leiden University. Free online: http://www.cmlca.eu/

ISO 14040 (2006) Environmental management: life cycle assessmentprinciples and framework, Secondth edn. ISO, Geneva

ISO 14044 (2006) Environmental management: life cycle assessmentrequirements and guidelines. Second edition. Geneva: ISO

Kadam KL (2002) Environmental benefit on a life cycle basis of using bagasse-derived ethanol as gasoline oxygenate in India. Energy Policy 30:371-384

Kelly KJ, Bailey BK, Coburn TC, Clark W, Lissiuk P (1996) Federal test procedure emissions test results from ethanol variable-fuel vehicle Chevrolet Luminas. In: International Spring Fuels and Lubricants Meeting. Dearborn, MI: Society for Automotive Engineers

Luo L, van der Voet E, Huppes G, Udo de Haes HA (2009a) Allocation issues in LCA methodology: a case study of corn stover-based fuel ethanol. Int J Life Cycle Assess 14:529-539

Luo L, van der Voet E, Huppes G (2009b) Life cycle assessment and life cycle costing of bioethanol from sugarcane in Brazil. Renew Sustain Energy Rev 13(6-7):1613-1619

Lynd LR, Wyman C, Laser M, Johnson D, Landucci R (2005) Strategic biorefinery analysis: analysis of biorefineries. NREL/ SR-510-35578, NREL

Mitchell R, Vogel KP, Sarath G (2008) Managing and enhancing switchgrass as bioenergy feedstock. Biofuels Bioprod Bioref 2:530-539
Nemecek T, Kägi T (2007) Life cycle inventories of Swiss and European Agricultural production systems. Ecoinvent report No. 15. Zurich and Dübendorf, December 2007

Nguyen TLT, Gheewala SH (2008) Life cycle assessment of fuel ethanol from cane molasses in Thailand. Int J Life Cycle Assess 13:301-311

Patyk A, Reinhardt GA (2002) LCA of bioethanol and ETBE. Internal report. Institute for Energy and Environmental Research (IFEU)

Reading AH, Norris JOW, Feest EA, Payne EL (2002) Ethanol Emissions Testing, AEAT Unclassified. E\&E/DDSE/02/021 2002, Issue 3

Renouf MA, Wegener MK, Nielsen LK (2008) An environmental life cycle assessment comparing Australian sugarcane with US corn and UK sugar beet as producers of sugars for fermentation. Biomass Bioenergy 32(12):1144-1155

Rosegrant MW, Paisner MS, Meijer S, Witcover J (2001) 2020 global food outlook: trends, alternatives, and choices. International Food Policy Research Institute, Washington

Schmer MR, Vogel KP, Mitchell RB, Perrin RK (2008) Net energy of cellulosic ethanol from switchgrass. PNAS 105(2):464-469

Searchinger T, Heimlich R, Houghton RA, Dong F, Elobeid A, Fabiosa J, Tokgoz S, Hayes D, Yu T (2008) Use of U.S. croplands for biofuels increases greenhouse gases through emissions from land-use change. Science 319:1238-1240

Shapouri H, McAloon A (2002) The 2001 net energy balance of cornethanol. U.S. Department of Agriculture, Washington D.C.

Sheehan J, Aden A, Paustian K, Killian K, Brenner J, Walsh M, Nelson R (2004) Energy and environmental aspects of using corn stover for fuel ethanol. J Ind Ecol 7(3-4):117-146

Silalertruksa T, Gheewala SH (2009) Environmental sustainability assessment of bio-ethanol production in Thailand. Energy 34 (11):1933-1946

Sokhansanj S, Mani S, Turhollow A, Kumar A, Bransby A, Lynd L, Laser M (2009) Large-scale production, harvest and logistics of switchgrass (Panicum virgatum L.) - current technology and envisioning a mature technology. Biofuels Bioprod Bioref 3:124-141

Spatari S, Zhang Y, Maclean HL (2005) Life cycle assessment of switchgrass- and corn stover-derived ethanol-fueled automobiles. Environ Sci Technol 39:9750-9758

Swiss Centre of Life Cycle Inventories. Ecoinvent database. Available online: http://www.ecoinvent.org/

Wooley R, Ruth M, Sheehan J, Ibsen K, Majdeski H, Galvez A (1999) Lignocellulosic biomass to ethanol process design and economics utilizing co-current dilute acid prehydrolysis current and futuristic scenarios. NREL/TP-580-26157

Wu M, Wang M, Huo H (2006) Fuel-cycle assessment of selected bioethanol production pathways in the United States. Energy System Division, Argonne National Laboratory 